\title{
ATTRIBUTES CONSIDERED BY COFFEE CONSUMERS DURING THEIR BUYING DECISION PROCESS: A STUDY USING FACTORIAL ANALYSIS
}

\begin{abstract}
The aim of this study was to identify, categorize and evaluate the attributes considered by the consumers during their coffee buying decision. A descriptive and quantitative survey with 459 coffee consumers was conducted in Belo Horizonte, MG, Brazil. The results indicate that the attributes considered by the consumers can be grouped into five factors based on importance: (i) Product features Organoleptic Characteristics, (ii) Brand and Tradition, (iii) Food safety, (iv) Availability and Product Offering, (v) Packaging. The theoretical contributions of this work are the identification of attributes considered by the consumers for buying coffee, the significance verification of these attributes, as well as the separation into factors, which allows a better understanding of the decision-making process of coffee consumers. The contributions of this research for management practices are related to the technical characteristics of the product, food safety, brand, label and packaging management, which are seen as very important factors. Moreover, distribution and trade marketing along the distribution channels are also aspects to be considered. These aspects must be worked out through integrated marketing communication. Finally, the research presents its limitations and several suggestions for future studies.
\end{abstract}

Fabiano Bento de Sá

Centro Universitário Una

Ricardo Viana Carvalho de Paiva

Centro Universitário Una

ricardovcp@gmail.com

Gustavo Quiroga Souki

Centro Universitário Una

gustavosouki@gmail.com

Luiz Rodrigo Cunha Moura

Centro Universitário Una

luizrcmoura@gmail.com

Recebido em: 13/09/2016. Aprovado em: 08/06/2017

Avaliado pelo sistema double blind review

Avaliador científico: Paulo Henrique Montagnana Vicente Leme

DOI: $10.21714 / 2238-68902017 v 19 n 2 p 084$

Keywords: Consumer behavior, Product attributes, Agribusiness, Evaluation of alternatives, Buying process.

\section{INTRODUCTION}

The current political, economic, cultural, social and technological transformations that are taking place all over the world have generated new market trends, affecting the behavior of consumers on food and beverages. Souki, Reis and Moura (2016) emphasize that the food consumers are becoming more mature, informed and demanding. Souki (2003) states that consumers are looking for healthier, fresh, natural and tasty foods. Furthermore, Neves, Castro and Fazanaro (2001) affirm that people's concerns about longevity, safety, and environmental conservation has resulted in the growing demand for high food and drink products quality, such as organics, free of additives (hormones, dyes, preservatives, stabilizers, among others) and environmentally friendly perspectives (biodegradable, recyclable, and wasteful of water and energy). In addition, consumers want their experience of buying and consuming food and beverage to be easier, more convenient and safer. For this reason, the comprehension of the consumer behavior and the decision-making process is therefore imperative for the agribusiness companies to develop effective marketing strategies.

Among the Brazilian agribusiness chains, coffee chain is one of the most traditional and important. This is because coffee was brought to Brazil in 1727 from the French Guiana, and spread rapidly due to Brazil's favorable climatic conditions. Coffee soon became the main product of the Brazilian economy, increasing its production and consumption in the late eighteenth century. For nearly a century, coffee was the great Brazilian product and the coffee economy accelerated the country's development and it's insertion in international trade relations (PIRES NETO, 2008). Nowadays, coffee is still of the major economic pillars of Brazilian national development and is responsible for the growth and wealth of many cities, making the country worldwide famous on that business. In economic and social terms, the production chain of coffee is responsible for generating more than eight million jobs in Brazil, through 287,000 producers approximately, 
mostly micro and small farmers (MINISTÉRIO DA AGRICULTURA, PECUÁRIA E ABASTECIMENTO, 2017). For those reasons, the history of coffee is associated with the country's own history (PIRES NETO, 2008). The International Coffee Organization (INTERNATIONAL COFFEE ORGANIZATION STATISTICS, 2016) points out that Brazil ranks second place in coffee consumption in the world (20.3 million - $60 \mathrm{~kg}$ bags), only surpassed by the United States (23.8 million - $60 \mathrm{~kg}$ bags). It is also noteworthy that Brazil is the world's largest producer and exporter of the product (ALMEIDA; ZYLBERSZTAJN, 2017). The world coffee production in 2015 was 144 million coffee bags, with Brazil responding to $42 \%$ of this production, while Vietnam was responsible for $19 \%$, Colombia (9\%), Indonesia (8\%), and Ethiopia (4\%).

According to ABIC (ASSOCIAÇÃO BRASILEIRA DA INDÚSTRIA DE CAFÉ, 2016), the per capita consumption of roasted coffee in 2015 was $4.9 \mathrm{~kg}$, which represents approximately 81 liters per year. Furthermore, coffee is present in $98.2 \%$ of households in Brazil and an average of 2.8 people per household drink coffee. The Euromonitor survey contracted by ABIC (ASSOCIAÇÃO BRASILEIRA DA INDÚSTRIA DE CAFÉ, 2010) revealed some consumer trends for the coming years. There is a further appreciation of the quality and certification of coffee by consumers, which means that good traditional, gourmet and certified coffees are growing. The markets for single-cup coffee, such as espresso coffee, sachet coffees, capsules and preparation services for strainer and filter also tend to grow. Finally, the growth of the use of domestic machines is also an important factor to observe in the consumption of coffee at home.

Although there are studies that deal with various aspects related to the behavior of coffee consumers (MOORI; BIDO; OLIVEIRA, 2011; QUINTÃO; BRITO, 2016; SAES; SPERS, 2006; SPERS; SAES; SOUZA, 2004; STRATTON; WERNER, 2013), most of them focus on aspects such as the intrinsic quality of the product, production and genetics (MAMATHA; REDDY, 2013; SILVA, et al., 2014; TOLEDO et al., 2016; VOSSEN; BERTRAND; CHARRIER, 2015). It is therefore understood that there is a trend in Brazilian studies towards presenting a technical approach, focusing on agronomic aspects and relegating consumer behavior, buying decision process and consumption of products to the background (PIRES NETO, 2008).

In view of the considerations above, the following guiding question was postulated: which are the attributes taken into account by coffee consumers in their buying decisions and how do these attributes can be classified into factors?
In this sense, the aim of this study was to identify, categorize and evaluate the attributes taken into account by consumers during their decision-making process for buying coffee, as well as categorizing these attributes into factors in order to understand the buying decision process.

The main theoretical contribution of this work refers therefore to the specification of the attributes considered by coffee consumers during their buying process. With regard to the managerial implications, this study is relevant for promoting the generation of knowledge for professionals, consumers, government institutions and stakeholders of the coffee's supply chain.

\section{LITERATURE REVIEW}

\subsection{Consumer Behavior and Buying Decision Process}

Blackwell, Miniard and Engel (2013), Mowen and Minor (2003), Schiffman and Kanuk (2009), Sheth, Mittal and Newman (2001), Solomon (2011) among other authors describe consumer behavior as physical and mental activities carried out by consumers, including the search for the product, purchase, use, evaluation and disposal of products, services, experiences and ideas that aim to meet one's needs.

Mowen and Minor (2003) claim that understanding consumers and consumption process provide a number of benefits such as (i) the provision of a knowledge support from which marketing researchers may analyze consumers; (ii) support to legislators and controllers in the elaboration of laws and regulations relating to the purchase and sale of goods and services; (iii) assistance to managers in their decision-making process; and (iv) assistance to consumers in making better buying decisions.

Furthermore, the knowledge of what consumers want and how they use products and make their buying decisions are critical information for succeeding in the market (SCHIFFMAN; KANUK, 2009; SHETH; MITTAL; NEWMAN, 2001). From the information obtained on the attributes of the products and/or services, managers are able to guide their efforts for improving or inserting attributes that are considered important in consumer buying decision process, thus generating competitive advantages through consumers' reviews (AZEVEDO; MOURA; SOUKI, 2015).

Blackwell, Miniard and Engel (2013) stand out among the authors whose models attempt to explain the consumer buying decision process by using steps of recognition of the necessity, search for information, 
evaluation of the alternatives, purchase, consumption, postpurchase evaluation, and disposal or recycling. During the step of evaluation of the alternatives, consumers evaluate the attributes of the products and services offered by each of the suppliers and/or brands. The consumers compare the options identified as potentially suitable to solve the problem that initiated the decision-making process and choose based on their beliefs, attitudes and intentions about the alternatives evaluated (MOWEN; MINOR, 2003). It was noticed that consumers rarely take into account all the alternatives during decision-making process. What usually happens is the choice from a restricted set of products or brands (BLACKWELL; MINIARD; ENGEL, 2013).

The major part of the effort expended on buying decision process is in the evaluation of the alternatives, since several options are offered (SOLOMON, 2011). The consumer must evaluate products and brands available in order to be persuaded for the final choice. There are two main procedures for carrying out the evaluation process. The first is the categorization process, in which the assessment depends on a specific category of the product. The second is called fragmented process, since it uses pieces of information to elaborate an evaluation of the options. In this process, the consumer chooses the product attributes to be evaluated and make judgments (BLACKWELL; MINIARD; ENGEL, 2013).

Some studies have already indicated the key attributes taken into account by the coffee consumers at the step of evaluation of the alternatives. Spers, Saes and Souza (2004) conducted a study that aimed at characterizing the behavior of coffee consumer in the markets of Belo Horizonte and Sao Paulo. The results showed that the main attributes that encourage the purchase were "having the seal of purity from ABIC", "taste", "brand", "quality" and "price", in that order of importance. The study also pointed out that being free of pesticides is the main variable identified by consumers and related to coffee production process.

Other authors conducted similar researches and assessed the perception of consumers about the importance of "sales (discounts, gifts, tasting)", "price", "quality", "position on the shelf", "brand", "brand tradition", "taste", "scent", "seal of purity", "ground coffee returns", "color", "roasting point", "source", "tasting and advertisements", and "packaging" (ARRUDA et al., 2009; GONÇALVES, 2009; LUNA; SETTE; SALAZAR, 2001; SANTOS; BITENCOURT, 2005).

Regarding the perception of consumers about packaging, Arruda et al. (2009) did not find consumers who value the package and place of purchase. However, Della Lucia et al. (2007) conducted a research to evaluate whether the package of organic ground coffees would interfere with the consumer buying intention and found that more than $55.5 \%$ of consumers always or often read the package and observe the label, price, expiry date, nutritional information, information on ingredients and additives. The authors also concluded that packaging and label influence the buying behavior of organic coffee at the same level of importance of quality characteristics during decision-making process (DELLA LUCIA et al., 2007).

Brazilian coffee growers have been developing strategies to create diversified products, such as "coffee from the countryside", "organic coffee", "coffee grown through good agricultural practices", which the consumers would be willing to pay higher prices because of the coffee quality (SAES; SPERS, 2006). Information such as "free of pesticides" and "does not harm the environment" on the package apparently pleases consumers and influences on buying decision process (DELLA LUCIA et al., 2007).

Outside Brazil, American consumers, for example, are also concerned with issues related to the fair trade in commercial relationships between farmers and the other companies of the coffee production chain (STRATTON; WERNER, 2013). In addition, Chinese consumers have the positive attitude of paying higher prices for coffee brands that have a fairer relationship with farmers (YANG et al., 2013), which may be $22 \%$ higher in some cases (YANG et al., 2012). It is very important to emphasize these aspects on packages and labels, because consumers are willing to pay more for this type of product and its more pleasant taste (SÖRQVIST et al., 2013). Moreover, study found forty-four feelings generated by coffee consumption (BHUMIRATANA; ADHIKARI; CHAMBERS, 2014). In relation to retail sales, this aspect is also important, since consumers are also more loyal to stores and coffee shops that work with these "eco-friendly" products or from fair trade relationships (JANGA; KIMA; LEE, 2015).

Complementing the studies and variables, Pires Neto (2008) identified three distinct consumer clusters in relation to the attributes considered important by coffee consumers in their buying decision process, through research conducted in Belo Horizonte and São Paulo. The first group considers essentially the coffee type for deciding. The second cluster considers the package as the most important aspect. The third group of consumers takes into account brand and package.

According to Varela, Beltrán and Fiszman (2014) coffee can be drunk pure, sweetened or not, with added 
milk or other substances, hot or cold. Therefore, the way the product is consumed, in addition to its various versions, is another point to be considered, which allows the formation of several clusters or different forms of decision-making.

\subsection{Intrinsic and Extrinsic Factors}

Both intrinsic and extrinsic factors influence the evaluation of products and services by consumers (GROHMANN, BATTISTELLA and SCHOEDLER, 2012; ZEITHAML, 1988). Intrinsic factors are related to attributes or features that compose the products, such as packaging, appearance, size, color and others. Extrinsic factors are also related to services and products, however, they are not related to the physical constitution, but refer to intangible aspects, such as services, advertising, price, brand and others (ZEITHAML, 1988).

Usually, the most important factor is the consumer's perception of the products, which may be understood as the process of organizing information in that regard. Nevertheless, the tangible characteristics of a product are not always the most important factor from the consumer's perspective (SHETH; MITTAL; NEWMAN, 2001).

Regarding the consumer's perception of value, it may be classified according to the following categories: the benefits of the product (technical, social or emotional), the financial amount spent or available credit and also the convenience (opening hours, location and others) and services (courtesy, good service, empathy, trust etc.) offered by companies (SHETH; MITTAL; NEWMAN, 2001), as well as the quality of the product and service (HARRINGTON; OTTENBACHER; KENDALL, 2011).

According to Zeithaml (1988), the intrinsic and extrinsic factors have different levels of influence on consumer behavior and product evaluation in different occasions. Most of the time the importance of extrinsic factors is greater when the consumer does not have a great knowledge about the product to be bought (that may be the first purchase) and therefore seeks information about its attributes and characteristics. It is also important to consider that the consumer may not be able to evaluate the intrinsic attributes of the product or think it is not worth doing that.

The intrinsic attributes are more important when consumer perceives high risk in the purchase of the product. Thus, the consumer will search for information - usually technical information and advices from other people - in order to make the best decision. The effort, time and amount of search for this information will depend on the level of risk that consumer perceives in buying or using the product and the possible negative consequences of this purchase. Furthermore, consumer's previous use of the product makes the evaluation of intrinsic attributes easier to be performed (ZEITHAML, 1988).

\section{METHODOLOGY}

This study aims to identify, categorize and evaluate the attributes considered by coffee consumers in their buying decision process in the city of Belo Horizonte, Minas Gerais, Brazil. That city has the sixth biggest population in Brazil, with 2,502,557 inhabitants (INSTITUTO BRASILEIRO DE GEOGRAFIA E ESTATÍSTICA, 2016) and it is the capital of the state that have the biggest coffee production in the country (MINISTÉRIO DA AGRICULTURA, PECUÁRIA E ABASTECIMENTO, 2017). Almeida and Zylbersztajn (2017) affirm that in Brazil the coffee production is concentrated in three states: Minas Gerais, Espirito Santo and Sao Paulo, which united account for $86 \%$ of the total production in the country. Furthermore, Minas Gerais alone is responsible for $52.75 \%$, and it is the major Arabic coffee producer (69.3\%).

This quantitative and descriptive research was conducted through a single cross-section survey involving coffee consumers residing in Belo Horizonte, Minas Gerais, Brazil. Prodanov and Freitas (2013) recommend this type of survey for carrying out research on consumer behavior.

Convenience and accessibility sampling techniques were used to collect data, which are two non-probability sampling examples (COOPER; SCHINDLER, 2001). Respondents from higher education institutions, companies and other places with large movement of people in the city were invited to participate in the survey. Those who agreed to participate went through an initial filter to verify whether they were part of the target audience. As a filter for the research, they were asked whether they drink coffee and its frequency. Only people who consume coffee one or more times per week were selected to complete the survey. At the end, 480 questionnaires were obtained, and after the analysis of outliers and absence of answers, a sample of 459 respondents was valid.

It should be noted that coffee consumers answered a semi-structured questionnaire, with an importance scale of eleven (11) points, in which (0) meant "low importance" and (10) represented "high importance" (ANTONIALLI; ANTONIALLI; ANTONIALLI, 2016). Before starting the application, the questionnaire was submitted to three marketing experts for evaluation and improvement of the research instrument used. The questionnaire included 17 attributes resulting from prior studies, as shown in Chart 1. 
CHART 1 - Attributes used for shaping the questionnaire

\begin{tabular}{|c|c|}
\hline Attributes & References \\
\hline 1) Being the brand that I am used to buy & $\begin{array}{l}\text { Spers, Saes and Souza (2004), Santos and Bitencourt (2005), Gonçalves (2009), Arruda } \\
\text { et al. (2009), Luna, Sette and Salazar (2001), Leme, Mário and Antonialli (2006). }\end{array}$ \\
\hline 2) Being a premium brand & Spers e Saes (2006) \\
\hline 3) The brand tradition & $\begin{array}{l}\text { Spers, Saes and Souza (2004), Santos and Bitencourt (2005), Gonçalves (2009), Arruda } \\
\text { et al. (2009), Luna, Sette and Salazar (2001), Leme, Mário and Antonialli (2006). }\end{array}$ \\
\hline 4) Having a low price & $\begin{array}{l}\text { Spers, Saes and Souza (2004), Santos and Bitencourt (2005), Gonçalves (2009), Arruda } \\
\text { et al. (2009), Luna, Sette and Salazar (2001), Leme, Mário and Antonialli (2006). }\end{array}$ \\
\hline 5) Being on sale & $\begin{array}{l}\text { Santos and Bitencourt (2005), Gonçalves (2009), Arruda et al. (2009), Luna, Sette } \\
\text { and Salazar (2001), Leme, Mário and Antonialli (2006). }\end{array}$ \\
\hline $\begin{array}{l}\text { 6) Being available in the location I was } \\
\text { making the purchase }\end{array}$ & Leme, Mário and Antonialli (2006). \\
\hline $\begin{array}{l}\text { 7) Having the necessary information on } \\
\text { the package label }\end{array}$ & Della Lucia et al. (2007), Pires Neto (2008) \\
\hline 8) The size of the package & Della Lucia et al. (2007), Pires Neto (2008) \\
\hline $\begin{array}{l}\text { 9) The type of packaging (padded, } \\
\text { vacuum, glass etc.) }\end{array}$ & Della Lucia et al. (2007), Pires Neto (2008) \\
\hline 10) Having recyclable packaging & Della Lucia et al. (2007), Spers and Saes (2006) \\
\hline 11) Having a pretty package & Della Lucia et al. (2007), Pires Neto (2008) \\
\hline 12) The coffee's taste (stronger/weaker) & $\begin{array}{l}\text { Spers, Saes and Souza (2004), Santos and Bitencourt (2005), Gonçalves (2009), Arruda } \\
\text { et al. (2009), Luna, Sette and Salazar (2001), Leme, Mário and Antonialli (2006). }\end{array}$ \\
\hline $\begin{array}{l}\text { 13) The type of coffee (organic, } \\
\text { gourmet, traditional, cappuccino etc.) }\end{array}$ & Pires Neto (2008) \\
\hline $\begin{array}{l}\text { 14) The roasting point of the coffee } \\
\text { (traditional, extra } \\
\text { strong etc.) }\end{array}$ & $\begin{array}{l}\text { Santos and Bitencourt (2005), Gonçalves (2009), Arruda et al. (2009), Luna, Sette } \\
\text { and Salazar (2001), Leme, Mário and Antonialli (2006). }\end{array}$ \\
\hline 15) The ground coffee returns & $\begin{array}{l}\text { Santos and Bitencourt (2005), Gonçalves (2009), Arruda et al. (2009), Luna, Sette } \\
\text { and Salazar (2001), Leme, Mário and Antonialli (2006). }\end{array}$ \\
\hline $\begin{array}{l}\text { 16) Having the seal of quality/purity } \\
\text { (ABIC Seal) }\end{array}$ & $\begin{array}{l}\text { Santos and Bitencourt (2005), Gonçalves (2009), Arruda et al. (2009), Luna, Sette and } \\
\text { Salazar (2001), Leme, Mário and Antonialli (2006), Spers, Saes and Souza (2004). }\end{array}$ \\
\hline 17) Being pesticide-free & Spers, Saes and Souza (2004) \\
\hline
\end{tabular}

Source: Prepared based on the authors cited

The data analysis was performed through descriptive and Exploratory Factor Analysis (HAIR et al., 2009; MALHOTRA, 2012; OSBORNE, 2015), using the software $\mathrm{IBM}^{\circledR}$ SPSS $^{\circledR}$ version 22 for the categorization of attributes in a smaller number of factors.

\section{RESULTS AND DISCUSSION}

This analysis was structured considering the purpose of identifying, evaluating, and categorizing the attributes considered by coffee consumers in their buying decisions in the city of Belo Horizonte, Brazil. However, the sample profile of this research will be initially presented.
The sample consisted predominantly of women $(63 \%)$ aged between 18 and 34 years $(62 \%)$. With respect to respondents' family income, it was found that $48.5 \%$ earn up to three thousand Reais (up to one thousand Dollars) per month and $16.3 \%$ of them earn more than eight thousand Reais a month (more than thousand and five hundred Dollars). Regarding the level of education, there is a higher frequency of consumers with higher education (44.4\%) and high school (31.6\%).

An Exploratory Factor Analysis (EFA) was performed in order to identify and evaluate the attributes taken into account by coffee consumers in their buying decision process. Principal component analysis (PCA) and direct oblimin rotation were used for the extraction, 
considering the existence of relationship between factors (HAIR et al., 2009; OSBORNE, 2015). At the first moment, the eigenvalue criterion was used to set the number of factors, representing the variance of the construct that is explained by each factor. According to this criterion, only factors with eigenvalues greater than 1 are taken into account, and there were found four factors. However, it was found that one of the factors mixed two different attributes, thus hindering its validity. It was therefore decided to force the factorial solution to find five factors, but ensuring they were responsible for at least $60 \%$ of the factor's explained variance (HAIR et al., 2009).

After application of EFA, forcing into five factors, it was verified its suitability to the data set, through the evaluation of two measures: (a) the Kaiser-Meyer-Olkin index (KMO) and (b) Bartlett's test of sphericity (BTS) (HAIR et al., 2009).

The KMO is the percentage of the data variance that can be attributed to a common factor, and ranges from 0.000 to 1.000 . The factorial solution is suitable when the measure has a value greater than 0.500 , and the closer it gets to 1,000 , the most appropriate the solution will be (MALHOTRA, 2012).

On the other hand, the BTS verifies whether the population correlation matrix is the identity matrix. This is used because applying EFA to data that behave as this type of matrix is not adequate. The suitability of the EFA is confirmed if the test of significance is less than 0.01 , which means that the population correlation matrix is not the identity (MALHOTRA, 2012).

Another important consideration to make is about the sufficiency of the number of respondents in relation to the number of variables used. The sample ought have at least five respondents for each variable used (HAIR et al., 2009; PARSIAN; DUNNING, 2009). A total of 459 respondents made up the survey sample and there were 17 variables related to the attributes. Therefore, the sample has 27 respondents for each variable, which confirms its suitability for application in this study.

After ensuring that the implementation of EFA was appropriate to the data set, it is necessary to check the quality of the found factorial solution. Three other measures are evaluated for this purpose: (a) the explained variance (EV), (b) the commonality and (c) the factor loading (FL). The first is the percentage from the total variation of the construct that all variables together are able to explain. It has a value between $0 \%$ and $100 \%$, and $60 \%$ is the minimum value for being considered adequate (MINGOTI, 2005). Commonality reflects how much each variable shares meaning with other variables and the factor loading and how much each variable shares meaning with the construct. Both have a value between 0.00 and 1.00, and values above 0.400 attest to the adequacy of the variable. Furthermore, the FL may not be higher than 0.400 and its value may not be near to more than one factor because it touches on the principle of unidimensionalilty, that is to say the factors measure different aspects of the concept. It was thus necessary to eliminate the variable "Having the necessary information on the package label" because it presented a very similar load on two factors. The variable "The ground coffee returns" was also eliminated from the analysis for not having validity with the factor in which it was loaded (HAIR et al., 2009).

After defining which variables belong to each of the five factors, their reliability was then verified through Cronbach's Alpha (CA). This measure ranges from 0.00 to 1.00 and represents the proportion of the scale's total variance that is assigned to the true score of the latent construct being measured (NETEMEYER; BEARDEN; SHARMA, 2003). As Malhotra (2012) points out, in this type of measure the reliability of the factor must be greater than 0.600 for scales in development and above 0.800 for already tested scales.

Chart 2 shows which measures should be evaluated (KMO, BTS, EV, Commonality, factor loading and Cronbach's Alpha) and the acceptable values according to the literature.

The five factors were named as follows:

- F1 - Package: includes appearance, type and size of the package and whether it is recyclable or not;

- F2 - Availability and supply: includes whether the product is on offer, have a low price and is available for immediate purchase;

- F3 - Product features: whether the product reflects the taste, type and roasting point of the coffee;

- F4 - Brand and tradition: reveals whether the brand is usually purchased, is a premium brand and has tradition; - F5 - Food safety: reveals whether the product is pesticide-free and possesses quality/purity seal.

Table 1 presents the EFA results regarding the five factors found for the attributes taken into account by coffee consumers in their buying decisions. Firstly, the KMO was 0.836 (over 0.600) and significance of BTS (Stat. $=2,412.96 ; \mathrm{DF}=105)$ was lower than $1 \%$. The total explained variance was $69.32 \%$, which is higher than the minimum specified. The variables that remained in the analysis showed both commonalities and factor loadings greater than 0.400 , and the CA of the factors were greater than 0.700 , which indicates adequate reliabilities. 
CHART 2 - Criteria for suitability of the factorial solution found

\begin{tabular}{|c|c|}
\hline Measure & Accepted standard \\
\hline Kaiser-Meyer-Olkin index (KMO) & $>0.600$ \\
Barlett's Test of Sphericity (BTS) & Lower than $1 \%$ \\
Explained variance (EV) & $>60 \%$ \\
Commonality ( ${ }^{2}$ ) & $>0.400$ \\
Factor Loading (FL) & $>0.400$ and may not be similar on two factors \\
Cronbach's Alpha & $>0.600$ (for scales in development) and $>0.800$ (for already tested scales) \\
\hline
\end{tabular}

Source: Hair et al. (2009), Malhotra (2012), Mingoti (2005) and Osborne, 2015

TABLE 1 - Factorial analysis of the attributes taken into account by coffee consumers in their buying decisions

\begin{tabular}{|c|c|c|c|c|c|}
\hline Factor & Attributes & Com. ${ }^{1}$ & $\mathrm{EV}^{2}$ & $\mathrm{FL}^{3}$ & $\mathrm{CA}^{4}$ \\
\hline \multirow{3}{*}{ F1 - Package } & Having a pretty package & 0.667 & \multirow{4}{*}{$33.66 \%$} & 0.829 & \multirow{4}{*}{0.831} \\
\hline & The type of packaging (padded, vacuum, glass etc.) & 0.735 & & 0.812 & \\
\hline & The size of the package & 0.698 & & 0.762 & \\
\hline \multirow{5}{*}{$\begin{array}{l}\text { F2 - Availability and } \\
\text { supply }\end{array}$} & Having recyclable packaging & 0.706 & & 0.597 & \\
\hline & Being on offer & 0.812 & \multirow{3}{*}{$11.84 \%$} & 0.897 & \multirow{3}{*}{0.726} \\
\hline & Having a low price & 0.789 & & 0.890 & \\
\hline & Being available in the place I was making the purchase & 0.508 & & 0.458 & \\
\hline & The coffee's taste (stronger/weaker) & 0.700 & \multirow{3}{*}{$8.99 \%$} & 0.844 & \multirow{3}{*}{0.715} \\
\hline \multirow[t]{2}{*}{ F3 - Product features } & $\begin{array}{l}\text { The type of coffee (organic, gourmet, traditional, } \\
\text { cappuccino, etc.) }\end{array}$ & 0.588 & & 0.727 & \\
\hline & The roasting point of the coffee (traditional, extra strong, etc.) & 0.623 & & 0.700 & \\
\hline \multirow{3}{*}{$\begin{array}{l}\mathrm{F} 4 \text { - Brand and } \\
\text { tradition }\end{array}$} & Being the brand that I am used to buy & 0.669 & \multirow{3}{*}{$8.66 \%$} & 0.824 & \multirow{3}{*}{0.731} \\
\hline & The brand tradition & 0.699 & & 0.818 & \\
\hline & Being a premium brand & 0.654 & & 0.737 & \\
\hline \multirow{2}{*}{ F5 - Food safety } & Pesticide-free & 0.793 & \multirow{2}{*}{$6.17 \%$} & -0.852 & \multirow{2}{*}{0.765} \\
\hline & Having the seal of quality/purity (ABIC Seal) & 0.758 & & -0.746 & \\
\hline
\end{tabular}

Source: Survey data

Subtitle: Com ${ }^{1}$ - Commonality; $\mathrm{EV}^{2}$ - Explained variance; $\mathrm{FL}^{3}$ - Factor loading; $\mathrm{CA}^{4}$ - Cronbach's Alpha

After EFA, the descriptive analysis of variables and factors was verified. The average values and standard deviations of the factors were obtained through a simple average of the variables that compose them.

Table 2 provides a detailed descriptive analysis of the attributes and factors taken into account by the coffee consumers in their buying decisions.

The factor "F3 - Product features" had the highest average and is the most importance in the consumer buying decision process. When the attributes that make up this factor are observed, it appears that the most relevant one is the coffee's taste, followed by the type of coffee and its roasting point, which had similar averages.
The second most relevant factor was "F4 - Brand and tradition", which averaged 6.85. Among its attributes, being the brand the respondent usually buys and being a traditional brand were considered more important than being a premium brand.

The third most important factor was "F5 Environment", which averaged 6.31, and its two attributes presented similar averages.

The fourth most important factor was "F2 Availability and supply", which averaged 6.08. The most important attribute was the availability of the product in the place the respondent was making the purchase, and the other two had smaller and similar averages. 
TABLE 2 - Factorial analysis of the attributes taken into account by coffee consumers in their buying decisions

\begin{tabular}{|c|c|c|c|c|c|c|c|c|c|}
\hline \multirow{2}{*}{ Factor } & \multirow{2}{*}{ Attributes } & \multicolumn{6}{|c|}{ Attributes } & \multicolumn{2}{|c|}{ Factor } \\
\hline & & $\mathrm{n}^{1}$ & $\mathrm{NR}^{2}$ & $\operatorname{Min}^{3}$ & $\operatorname{Max}^{4}$ & Average $^{5}$ & $\mathrm{SD}^{6}$ & Average $^{7}$ & $\mathrm{SD}^{8}$ \\
\hline \multirow{5}{*}{ F1 - Package } & Having a nice package & 453 & 6 & 0 & 10 & 4.66 & 3.72 & \multirow{4}{*}{4.50} & \multirow{4}{*}{3.61} \\
\hline & $\begin{array}{c}\text { The type of packaging (padded, } \\
\text { vacuum, glass etc.) }\end{array}$ & 454 & 5 & 0 & 10 & 4.58 & 3.66 & & \\
\hline & The size of the package & 455 & 4 & 0 & 10 & 4.81 & 3.60 & & \\
\hline & Having recyclable packaging & 455 & 4 & 0 & 10 & 3.96 & 3.47 & & \\
\hline & Being on sale & 454 & 5 & 0 & 10 & 5.69 & 3.32 & \multirow{3}{*}{6.08} & \multirow{3}{*}{3.22} \\
\hline \multirow{2}{*}{$\begin{array}{l}\text { F2 - } \\
\text { Availability } \\
\text { and supply }\end{array}$} & Having a low price & 455 & 4 & 0 & 10 & 5.64 & 3.29 & & \\
\hline & $\begin{array}{l}\text { Being available in the place I } \\
\text { was making the purchase }\end{array}$ & 456 & 3 & 0 & 10 & 6.90 & 3.04 & & \\
\hline \multirow{3}{*}{$\begin{array}{l}\text { F3 - Product } \\
\text { features }\end{array}$} & $\begin{array}{l}\text { The coffee's taste (stronger/ } \\
\text { weaker) }\end{array}$ & 458 & 1 & 0 & 10 & 7.87 & 2.68 & \multirow{3}{*}{7.16} & \multirow{3}{*}{3.18} \\
\hline & $\begin{array}{l}\text { The type of coffee (organic, } \\
\text { gourmet, traditional, } \\
\text { cappuccino, etc.) }\end{array}$ & 454 & 5 & 0 & 10 & 6.75 & 3.46 & & \\
\hline & $\begin{array}{l}\text { The roasting point of the coffee } \\
\text { (traditional, extra strong, etc.) }\end{array}$ & 453 & 6 & 0 & 10 & 6.86 & 3.40 & & \\
\hline \multirow{3}{*}{$\begin{array}{l}\text { F4 - Brand } \\
\text { and tradition }\end{array}$} & $\begin{array}{l}\text { Being the brand that I am used } \\
\text { to buy }\end{array}$ & 456 & 3 & 0 & 10 & 7.84 & 2.98 & \multirow{3}{*}{6.85} & \multirow{3}{*}{3.22} \\
\hline & The brand tradition & 453 & 6 & 0 & 10 & 7.18 & 3.12 & & \\
\hline & Being a premium brand & 452 & 7 & 0 & 10 & 5.54 & 3.55 & & \\
\hline \multirow{2}{*}{$\begin{array}{l}\text { F5 - Food } \\
\text { safety }\end{array}$} & Be pesticide-free & 450 & 9 & 0 & 10 & 6.13 & 3.85 & \multirow[b]{2}{*}{6.31} & \multirow[b]{2}{*}{3.76} \\
\hline & $\begin{array}{l}\text { Having the seal of quality/purity } \\
\text { (ABIC Seal) }\end{array}$ & 453 & 6 & 0 & 10 & 6.50 & 3.68 & & \\
\hline
\end{tabular}

Source: Survey data

Subtitle: $\mathrm{n}^{1}$ - Number of respondents to the question; $\mathrm{NR}^{2}$ - Number of respondents who did not answer the question; Min ${ }^{3}$ - Minimum value assigned to the item; $\mathrm{Max}^{4}$ - Maximum value assigned to the item; Average ${ }^{5}$ - Average value of the item; $\mathrm{SD}^{6}-\mathrm{Standard}$ deviation; Average $\mathrm{e}^{7}$ Average value of the factor; $\mathrm{SD}^{8}$ - Standard deviation

The fifth and less important factor was "F1 Packing". The attributes presented similar averages, with the exception of whether or not the package was recyclable, which showed lower average.

The factors F1 - Packaging, F3 - Product features, and F5 - Food safety may be seen as intrinsic attributes of the product. On the other hand, the extrinsic attributes are represented by F2 - Availability and supply and F4 Brand and tradition. In terms of importance, the factor F3 - Product features was rated as the most important and it is directly linked to the organoleptic characteristics of coffee.

In terms of consumer appreciation, the results of this study are consistent with those found by Spers, Saes and Souza (2004), in relation to the organoleptic characteristics of coffee, and with those found by Della Lucia et al. (2007). This study is also in line with those developed by Arruda et al. (2009), Gonçalves (2009), Leme, Mário and Antonialli (2006), Luna, Sette and Salazar (2001), Santos and Bitencourt (2005), especially regarding to being pesticidefree and having the seal of quality and purity from ABIC. In the case of package, which had the lowest note and averaged below five points, the results are consistent with those found by Arruda et al. (2009), who describe its low relevance, in contrast to the results obtained by Della Lucia et al. (2007), who consider that coffee packaging strongly influences buying behavior and consumer choice.

Finally, the standard deviation values were high for all factors. This information indicates a divergence among respondents regarding all attributes. Therefore, in summary, there is a large group of people who take into account the most relevant factors in their decisionmaking process of choosing the type of product, and there 
is another large group of people who take into account unimportant factors in that same process. This result suggests that future study might identify, through analysis of clustered data, different behavioral patterns among groups of coffee consumers with regard to the attributes taken into account in their buying decision process.

\section{FINAL CONSIDERATIONS}

The theoretical contributions of this work were: (a) identifying the attributes taken into account by coffee consumers regarding their choice of the product; (b) recognition of the relevance of these attributes, as well as (c) the formation of factors that allow a better understanding of consumer's decision-making process in relation to coffee.

There are also several contributions in management terms. With regard to product management, it appears that professionals who work with coffee marketing analyze the technical characteristics of the product and the brand, label and packaging management, which are seen as important factors.

Moreover, distribution and trade marketing along the distribution channels in order to make the product available to the consumer and offer convenience and ease of purchase are also aspects to be considered. According to this research, availability and supply influences the price perception among consumers.

With respect to marketing communication, there are many possibilities for managers, who should enhance and strengthen their perception and positive associations related to the brand value, in addition to product's tradition and benefits to the consumer. Moreover, environmental aspects should also be shown to the target audience, as a highlight. These aspects must be worked out through integrated marketing communication using all means available to the companies nowadays, such as mass advertising, events, public relations, social media, institutional sites, among others.

\section{RESEARCH LIMITATIONS AND SUGGESTIONS FOR FUTURE RESEARCH}

Regarding the limitations of this work, it is possible to mention the use of cross-section data, since it does not consider that various factors may change over time, affecting coffee consumer's behavior. In this way, it does not allow a deep understanding of the situation and the changes occurred, since the information are only collected once. The adoption of convenience and accessibility sampling techniques constitutes another limitation, since it precludes inferences on the population of coffee consumers.
Furthermore, this research bases itself on the use of variables from other experiments carried out. It is suggested to conduct qualitative studies in order to identify potential variables that may represent the perception of consumers and were not included in this work.

As suggestions for further research, it may be useful to study specific types of coffee (e.g. organic, gourmet, capsules, cappuccino, espresso, instant etc.), emphasizing the socio demographic variables and analyzing psychographic segmentation criteria such as personality and lifestyle of coffee consumers. Such studies may contribute to better characterization of the different consumer profiles.

It is suggested to conduct research with larger samples, including cities in other regions, or even comparing the results with other states, since the coffee choice has strong regional appeal.

The adoption of longitudinal data is recommended, as well as carrying out related research in another time, since consumer behavior may change due to external influences, such as cultural, social and others.

Other studies might be conducted focusing on the phase of post-purchase evaluation and the impact evaluation of the perceived quality by consumers on their behavioral intentions regarding coffee. Another suggestion for future research would be to develop a blind test research to compare the declared and actual perception of the consumers. Finally, considering the conflicting results found among different authors about the importance of package for assessing the coffee consumer, there is a need for studies to fill this gap on the coffee consumer's behavior.

\section{REFERENCES}

ALMEIDA, L. F. de; ZYLBERSZTAJN, D. Key success factors in the brazilian coffee agrichain: present and future challenges. Journal on Food System Dynamics, Bonn, v. 8, n. 1, p. 45-53, Jan. 2017.

ANTONIALLI, F.; ANTONIALLI, L. M.; ANTONIALLI, R. Usos e abusos da escala likert: estudo bibliométrico nos anais do Enanpad de 2010 a 2015. In: CONGRESSO DE ADMINISTRAÇÃO, SOCIEDADE E INOVAÇÃO, 2016, Juiz de For a. Anais... Juiz de Fora: CASI, 2016. p. 4494-4516.

ARRUDA, A. C. et al. Justificativas e motivações do consumo e não consumo de café. Ciência e Tecnologia de Alimentos, Campinas, v. 29, n. 4, p. 754-763, out./ dez. 2009. 
ASSOCIAÇÃO BRASILEIRA DA INDÚSTRIA DE CAFÉ - ABIC. Indicadores da indústria de café no Brasil - 2015. ABIC, Rio de Janeiro, 2016. Disponível em: $<$ http://www.abic. com.br/publique/cgi/cgilua.exe/sys/ start.htm?sid=61\#1910>. Acesso em: 2 maio 2017.

Tendências de consumo de café 2010 . Rio de Janeiro: ABIC, 2010. 108 p. Disponível em: <http:// www.abic.com.br/publique/media/EST_PESQTendencias Consumo2010.pdf $>$. Acesso em: 2 maio 2017.

AZEVEDO, L. das M. R. P. P.; MOURA, L. R. C.; SOUKI, G. Q. Um estudo qualitativo dos atributos para a escolha de um restaurante. Revista Acadêmica São Marcos, Alvorada, v. 5, n. 1, p. 25-51, jan./jun. 2015.

BHUMIRATANA, N.; ADHIKARI, K.; CHAMBERS, E. The development of an emotion lexicon for the coffee drinking experience. Food Research International, Toronto, v. 61, p. 83-92, July 2014.

BLACKWELL, R. D.; MINIARD, P. W.; ENGEL, J. F. Comportamento do consumidor. São Paulo: Cengage Learning, 2013. 606 p.

COOPER, D. R.; SCHINDLER, P. S. Métodos de pesquisa em administração. 7. ed. São Paulo: Bookman, 2001. 636 p.

DELLA LUCIA, S. M. et al. Fatores da embalagem de café orgânico torrado e moído na intenção de compra do consumidor. Ciência e Tecnologia de Alimentos, Campinas, v. 27, n. 3, p. 485-491, set. 2007.

GONÇALVES, A. C. A. Desenvolvimento de bebida à base de café adicionada de concentrado proteico de soro: da pesquisa mercadológica à avaliação sensorial. 2009. 132 f. Tese (Doutorado em Ciência e Tecnologia de Alimentos) - Universidade Federal de Viçosa, Viçosa, 2009.

GROHMANN, M. Z.; BATTISTELLA, L. F.; SCHOEDLER, A. R. Atributos importantes para o consumidor de automóveis: classificação em função instrumental ou expressiva. Faces: revista de administração, Belo Horizonte, v. 11, n. 1, p. 67-86, jan./mar. 2012.

HAIR, J. F. et al. Análise multivariada de dados. 6. ed. Porto Alegre: Bookman, 2009. 593 p.
HARRINGTON, R. J.; OTTENBACHER, M. C.; KENDALL, K. W. Fine-dining restaurant selection: direct and moderating effects of customer attributes. Journal of Foodservice Business Research, New York, v. 14, n. 3, p. 272-289, Aug. 2011.

INSTITUTO BRASILEIRO DE GEOGRAFIA E ESTATÍSTICA - IBGE. 2016. Disponível em: <http:// www.ibge.gov.br/home/>. Acesso em: 18 maio 2016.

INTERNATIONAL COFFEE ORGANIZATION STATISTICS - ICO. Disponível em: $<$ http://www.ico.org/ trade_statistics.asp?-section=Statistics $>$. Acesso em: 18 maio 2016 .

JANGA, Y. J.; KIMA, W. G.; LEE, H. Y. Coffee shop consumers' emotional attachment and loyalty to green stores: the moderating role of green consciousness. International Journal of Hospitality Management, Ames, v. 44, p. 146-156, Jan. 2015.

LEME, P. H. M. V.; MÁRIO, T. M. do C.; ANTONIALLI, L. M. Identificação de segmentos no mercado consumidor de café na cidade de São Paulo. In: SOCIEDADE BRASILEIRA DE ECONOMIA, ADMINISTRAÇÃO E SOCIOLOGIA RURAL, 44., 2006, Fortaleza. Anais... Fortaleza: SOBER, 2006. p. 1-17.

LUNA, R. M.; SETTE, R. de S.; SAlAZAR, G. T. Comportamento do consumidor em relação à certificação de origem do café. In: SIMPÓSIO DE PESQUISA DOS CAFÉS DO BRASIL, 2., 2001, Vitória. Anais... Vitória: Embrapa, 2001. p. 2145-2153.

MAlhotra, N. K. Pesquisa de marketing: uma orientação aplicada. Porto Alegre: Bookman, 2012. 768 p.

MAMATHA, N. C.; REDDY, B. V. C. Impact of organic coffee production on ecological variable and consumers' willingness to pay for organic coffee. Mysore Journal of Agricultural Sciences, Bangalore, v. 47, n. 3, p. 622-627, 2013.

MINGOTI, S. Análise de dados através de métodos de estatística multivariada: uma abordagem aplicada. Editora UFMG, 2005. 295 p.

MINISTÉRIO DA AGRICULTURA, PECUÁRIA E ABASTECIMENTO - MAPA. Café no Brasil. Mapa, Brasília, jan. 2017. Disponível em: <http://www. agricultura.gov.br/assuntos/ politica-agricola/cafe/ cafeicultura-brasileira $>$. Acesso em: 8 maio 2017. 
MOORI, R. G.; BIDO, D. S.; OLIVEIRA, L. H. Variáveis relevantes do consumidor do café solúvel sob o enfoque da diferenciação. Organizações Rurais \& Agroindustriais, Lavras, v. 13, n. 1, p. 124-138, 2011.

MOWEN, J. C.; MINOR, M. S. Comportamento do consumidor. São Paulo: Prentice Hall, 2003. 413 p.

NETEMEYER, R. G.; BEARDEN, W. O.; SHARMA, S. Scaling procedures: issues and applications. SAGE, 2003. $206 \mathrm{p}$.

NEVES, M. F.; CASTRO, L. T.; FAZANARO, K. Marketing e o novo consumidor de alimentos. Alimentos e Tecnologia Business, Santa Maria, v. 1, p. 34-38, 2001.

OSBORNE, J. W. What is rotating in exploratory factor analysis? Practical Assessment, Research \& Evaluation, Guildford, v. 20, n. 2, p. 1-7, Jan. 2015.

PARSIAN, N.; DUNNING, T. Developing and validating a questionnaire to measure spirituality: a psychometric process. Global Journal of Health Science, Toronto, v. 1, n. 1, p. 2-12, Apr. 2009.

PIRES NETO, G. B. A. Atributos utilitários que afetam a decisão de compra do café em pó: uma investigação no município do Rio de Janeiro. 2008. 96 f. Dissertação (Mestrado em Administração e Desenvolvimento Empresarial) Universidade Estácio de Sá, Rio de Janeiro, 2008.

PRODANOV, C. C.; FREITAS, E. C. Metodologia de trabalho científico: métodos e técnicas da pesquisa e do trabalho acadêmico. Novo Hamburgo: Feevale, 2013. $277 \mathrm{p}$.

QUINTÃO, R. T.; BRITO, E. Z. Connoisseurship consumption and market evolution: an institutional theory perspective on the growth of specialty coffee consumption in the USA. Revista Brasileira de Marketing, São Paulo, v. 15, n. 1, p. 1-15, jan./mar. 2016.

SAES, M. S. M.; SPERS, E. E. Percepção do consumidor sobre os atributos de diferenciação no segmento rural: café no mercado interno. Organizações Rurais \& Agroindustriais, Lavras, v. 8, n. 3, p. 354-367, nov. 2006.

SANTOS, Z. A. da S.; BITENCOURT, M. B. Análise do mercado de café em Belo Horizonte/MG: uma visão da percepção do consumidor. In: CONGRESSODASOCIEDADE BRASILEIRA DE ECONOMIA, ADMINISTRAÇÃO E SOCIOLOGIA RURAL, 43., 2005, Ribeirão Preto. Anais... Ribeirão Preto: SOBER, 2005. p. 1-16.

SCHIFFMAN, L. G.; KANUK, L. L. Comportamento do consumidor. Rio de Janeiro: LTC, 2009. 460 p.

SHETH, J. N.; MitTAL, B.; NEWMAN, B. I. Comportamento do cliente: indo além do comportamento do consumidor. São Paulo: Atlas, 2001. 795 p.

SILVA, P. A. et al. Quality assessment of coffee grown in Campos Gerais, Minas Gerais State, Brazil. Acta Scientiarum, Maringá, v. 36, n. 4, p. 739-744, out./dez. 2014.

SOLOMON, M. R. Comportamento do consumidor: comprando, possuindo e sendo. Porto Alegre: Bookman, $2011.608 \mathrm{p}$.

SÖRQVIST, P. H. D. et al. Who needs cream and sugar when there is eco-labeling? Taste and willingness to pay for "eco-friendly" coffee. PLoS One, San Francisco, v. 8, n. 12, p. 1-9, Dec. 2013.

SOUKI, G. Q. Estratégias de marketing para os agentes da cadeia da carne bovina. 2003. 228 p. Tese (Doutorado em Administração) - Universidade Federal de Lavras, Lavras, 2003.

SOUKI, G. Q.; REIS, V. C.; MOURA, L. R. C. The behavior of bakery consumers. Organizações Rurais \& Agroindustriais, Lavras, v. 18, n. 1, p. 1-12, 2016.

SPERS, E. E.; SAES, M. S. M.; SOUZA, M. C. M. de. Análise das preferências do consumidor brasileiro de café: um estudo exploratório dos mercados de São Paulo e Belo Horizonte. Revista de Administração da Universidade de São Paulo, São Paulo, v. 39, n. 1, p. 53-61, jav./mar. 2004.

STRATTON, J. P.; WERNER, M. J. Consumer behavior analysis of fair trade coffee: evidence form filed research. The Psychological Record, Carbondale, v. 63, n. 2, p. 363-374, Mar. 2013.

TOLEDO, P. R. A. B. et al. Relationship between the different aspects related to coffee quality and their volatile compounds. Comprehensive Reviews in Food Science and Food Safety, Essex, v. 15, n. 4, p. 705-719, July 2016. 
VAN DER VOSSEN, H.; BERTRAND, B.; CHARRIER, A. Next generation variety development for sustainable production of arabica coffee (Coffea arabica $\mathrm{L}$.): a review. Euphytica, Wageningen, v. 204, n. 2, p. 243-256, July 2015.

VARELA, P.; BELTRÁN, J.; FISZMAN, S. An alternative way to uncover drivers of coffee liking: preference mapping based on consumers' preference ranking and open comments. Food Quality and Preference, New York, v. 32, p. 152-159, Mar. 2014.

YANG, S. et al. Consumer willingness to pay for fair trade coffee: a chinese case study. Journal of Agricultural and
Applied Economics, Cambridge, v. 44, n. 1, p. 21-34, Feb. 2012.

. Using a modified payment card survey to measure chinese consumers' willingness to pay for fair trade coffee: considering starting points. Canadian Journal of Agricultural Economics, Victoria, v. 61, n. 1, p. 119-139, Mar. 2013.

ZEITHAML, V. A. Consumer perceptions of price, quality, and value: a means-end model and synthesis of evidence. Journal of Marketing, Chicago, v. 52, n. 2, p. 2-22, July 1988. 